\title{
About California Agriculture
}

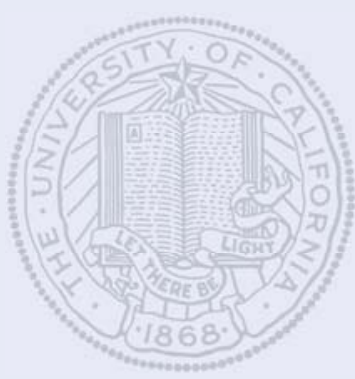

University of California

Agriculture and Natural Resources
California Agriculture is a quarterly, peer-reviewed journal reporting research and reviews, published by the University of California Agriculture and Natural Resources (ANR). The first issue appeared in 1946, making California Agriculture one of the oldest, continuously published, land-grant university research journals in the country. There are about 17,000 print subscribers, and the electronic journal logs about 5 million page views annually.

Mission and audience. California Agriculture publishes refereed original research in a form accessible to a well-educated audience. In the last readership survey, 33\% worked in agriculture, 31\% were university faculty or research scientists, and 19\% worked in government agencies or were elected office holders.

Electronic version of record. In July 2011, the electronic journal became the version of record; it includes printed and electronic-only articles. When citing or indexing articles, use the electronic publication date.

Indexing. The journal is indexed by AGRICOLA Current Contents (Thomson ISI's Agriculture, Biology and Environmental Sciences and the SCIE databases), Commonwealth Agricultural Bureau (CAB), EBSCO (Academic Search Complete), Gale (Academic OneFile), Proquest and others, including open-access databases. It has high visibility on Google and Google Scholar searches. All peer-reviewed articles are posted to the ANR and California Digital Library eScholarship repositories.

Authors and reviewers. Authors are primarily but not exclusively from ANR; in 2010 and 2011, 23\% were based at other UC campuses, or other universities and research institutions. In 2010 and 2011, 33\% and 40\% (respectively) of reviewers came from universities, research institutions or agencies outside ANR.

Rejection rate. The rejection rate has averaged $34 \%$ in the last 3 years. In addition, associate editors and staff may send back manuscripts for revision prior to peer review.

Peer-review policies. All manuscripts submitted for publication in California Agriculture undergo double-blind, anonymous peer review. Each submission is forwarded to the appropriate associate editor for evaluation, who then nominates three qualified reviewers. If the first two reviews are affirmative, the article is accepted. If one is negative, the manuscript is sent to the third reviewer. The associate editor makes the final decision, in consultation with the managing and executive editors.

Editing. After peer review and acceptance, all manuscripts are extensively edited by the California Agriculture staff to ensure readability for an educated lay audience and multidisciplinary academics.

Submissions. California Agriculture manages the peer review of manuscripts online. Please read our Writing
Guidelines before submitting an article; go to: http://californiaagriculture.ucanr.edu/submit.cfm.

Letters. The editorial staff welcomes your letters, comments and suggestions. Please write to us at the address below. Include your full name and address. Letters may be edited for space and clarity.

Subscriptions. These are free within the United States and \$24 per year abroad. Single copies are \$5 each. Go to: http://californiaagriculture.ucanr.edu/ subscribe.cfm or write us. International orders must include check or money order in U.S. funds, payable to UC Regents. MasterCard/Visa accepted; include address, signature and expiration date.

Permissions. Articles may be reprinted provided that no advertisement for a commercial product is implied or imprinted. Please credit California Agriculture, University of California, citing volume and number, or complete date of issue, followed by inclusive page numbers. Indicate (C[[year]] The Regents of the University of California. Photographs in print or online may not be reprinted without permission.

\section{California Agriculture}

Peer-reviewed research and news published by University of California Agriculture and Natural Resources

VOLUME 66, NUMBER 4

1301 S. 46th St., Bldg. 478, Richmond, CA 94804-4600 Phone: (510) 665-2163; Fax: (510)665-3427; calag@ucanr.edu http://californiaagriculture.ucanr.edu

Executive Editor: Janet White Senior Editor: Hazel White Art Director: Will Suckow Administrative Support: Carol Lopez, María Muñoz, Sandra K. Willard

Associate Editors

Animal, Avian, Aquaculture \& Veterinary Sciences: Bruce Hoar, Carolyn Stull, Lisa C. Thompson Economics \& Public Policy: Peter Berck, Rachael Goodhue, Karen Klonsky, Mark Lubell

Food \& Nutrition: Amy Block Joy, Sharon E. Fleming, Sheri Zidenberg-Cherr

Human \& Community Development: David Campbell, Richard Ponzio, Ellen Rilla

Land, Air \& Water Sciences: Mark E. Grismer, Kenneth Tate Shrinivasa K. Upadhyaya, Bryan Weare

Natural Resources: Adina Merenlender, Kevin O'Hara, Richard B. Standiford

Pest Management: Kent Daane, Joseph DiTomaso, Deborah A. Golino, Joseph Morse, James Stapleton

Plant Sciences: Kent Bradford, Kevin R. Day, Joseph Grant, Rachael F. Long, Carol Lovatt

California Agriculture (ISSN 0008-0845, print, linking; ISSN 2160-8091, online) is published quarterly and mailed at periodicals postage paid at Richmond, CA, and additional mailing offices. Postmaster: Send change of address "Form 3579" to California Agriculture at the address above.

(O) 2012 The Regents of the University of California 